Ferri Alfadri: Pengaruh Adanya Transportasi Online

\title{
PENGARUH ADANYA TRANSPORTASI ONLINE \\ TERHADAP KESEJAHTERAAN MASYARAKAT MELALUI VARIABEL PEN- GANGGURAN DI KOTA MEDAN
}

\author{
Ferri Alfadri \\ Mahasiswa Pascasarjana Prodi EKNI UIN Sumatera Utara, Medan \\ e-mail : ferrialfadri2809@gmail.com
}

\begin{abstract}
ABSTRAK
Penelitian ini bertujuan untuk melakukan penelitian langsung terkait dengan pengaruh munculnya sistem transportasi online di dalam kehidupan masyarakat yang ditinjau dari aspek pengangguran dan juga kesejahteraan masyarakat di Kota Medan. Penelitian ini dilakukan pada PT. GO-JEK Indonesia di kota Medan Provinsi Sumatera Utara dengan menggunakan metode kuantitatif. Pada penelitian ini menggunakan teknik analisis metode SEM dengan bantuan program Smart PLS. Berdasarkan hasil perhitungan statistik setelah diteliti, maka dapat disimpulkan bahwa : adanya transportasi online berpengaruh positif sifnifikan terhadap tingkat pengangguran secara langsung. Hal ini dapat di buktikan dari nilai t-statistik sebesar 86,750, adanya transportasi online berpengaruh positif sifnifikan terhadap Kesejahteraan secara langsung. Hal ini dapat di buktikan dari nilai t-statistik sebesar 5,638, dan dengan adanya transportasi online berpengaruh positif signifikan terhadap Kesejahteraan secara langsung melalui variabel pengangguran. Hal ini dapat di buktikan dari nilai t-statistik sebesar 4,880. Dengan demikian, hipotesis $\mathrm{H}_{1}, \mathrm{H}_{2}$ dan $\mathrm{H}_{3}$ dalam penelitian ini diterima.
\end{abstract}

Kata Kunci : Transportasi online, GO-JEK, Pengangguran dan Kesejahteraan.

\section{ABSTRACT}

Research this aim for conduct direct research related to the influence of the emergence of an online transportation system in the life of the community in terms of aspects of unemployment and also the welfare of the people in Medan City. This research was conducted at PT. GO-JEK Indonesia in Medan, North Sumatra Province with use method quantitative. On research this use technique SEManalysis methods with the help of Smart PLS program. Based on the results of statistical calculations after researched, then can be concluded that: the existence of online transportation has a significant positive effect on the unemployment rate directly. This can be proven from the t-statistics value of 86,750 , the existence of online transportation has a significant positive effect on welfare directly. This can be proved from the t-statistics value of 5,638 , and with their online transportation positive 5,638 , effect on the welfare of the signifikcant directly through vari- 
able unemployment. This can be proven from the t-statistics value of 4,880. Thus, the $\mathrm{H}_{1}, \mathrm{H}_{2}$ and $\mathrm{H}_{3}$ hypothesis in this study was accepted.

Keywords: Transportation online , GO-JEK, Unemployment and Prosperity

\section{PENDAHULUAN}

Terjadinya gejala ketimpangan antara pertambahan persediaan tenaga kerja dengan struktur kesempatan kerja menurut jenjang pendidikan, menunjukkan terjadinya gejala, semakin tinggi tingkat pendidikan, semakin besar angka penggangguran potensialnya. (Suryadi, 1994)

Namun, beberapa tahun belakangan ini muncul berbagai pilihan untuk masyarakat baik yang berpendidikan atau pun yang kurang pendidikan nya untuk tetap dapat bekerja dan menghasilkan uang untuk keperluan sehari-hari dengan menggunakan bantuan teknologi gadget/smartphone yang ada yaitu sistem transportasi online seperti: GO-JEK, Grab, Uber dan NGUBERJEK. Banyak dari masyarakat baik yang pengangguran dan juga yang sudah bekerja berbondong-bondong mendaftarkan diri ke salah satu pilihan PT ini (Kemendagri, 2018). Hal inilah yang memicu semakin tingginya tingkat pertumbuhan pengemudi sistem transportasi online.

Sedangkan alasan konsumen memilih atau menggunakan sistem transportasi online juga cukup beragam, secara umum dinilai beranggapan bahwa sistem transportasi online lebih murah (84,1 persen), dan lebih cepat (81, 9 persen). Seperti terlihat di gambar

\section{Gambar .1 Alasan Konsumen Memilih Sistem Sistem transportasi online}

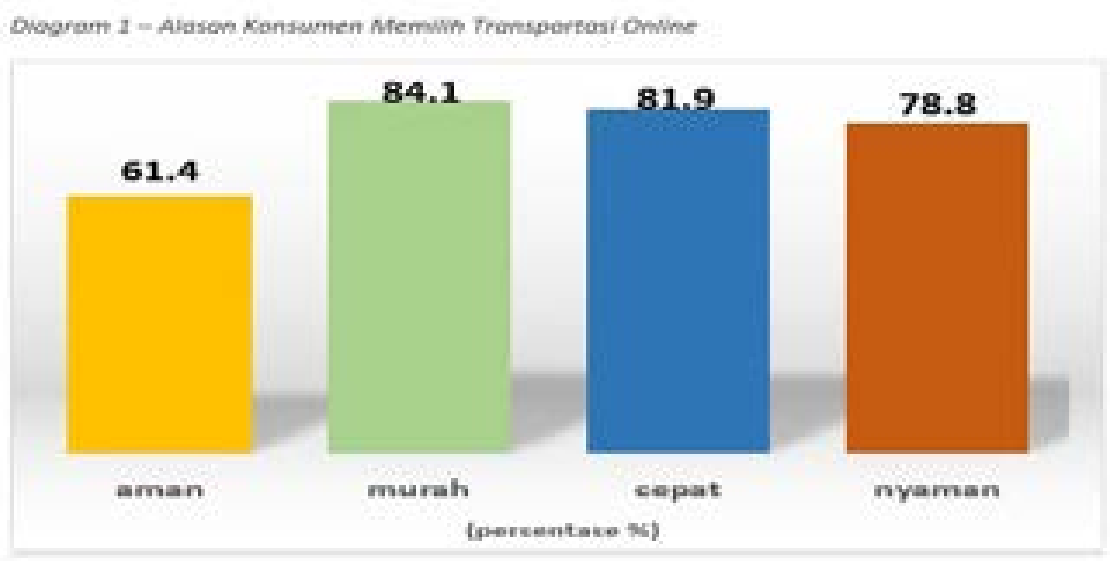

Dari gambar 1 terlihat bahwa faktor harga menjadi pertimbangan mayoritas konsumen. 
Ferri Alfadri: Pengaruh Adanya Transportasi Online

Responden beranggapan sistem transportasi online lebih murah jika disandingkan dengan tarif jenis transportasi konvensional. Di urutan kedua, konsumen memilih sistem transportasi online karena dianggap lebih cepat. Namun dalam survei ini tidak mengelaborasi lebih dalam, yang dimaksud adalah lebih cepat ditemukan/ diakses (accessible) atau lebih cepat mencapai tujuan. (riska, 2018)

Seiring dengan semakin tingginya minat dari para pengguna jasa transportasi berbasis online inilah penulis beranggapan akan semakin besar pula peluang masyarakat untuk menjadi driver atau pengemudi jasa angkutan transportasi berbasis online. Hal itu bisa di nilai dengan semakin berkembangnya jumlah para driver yang semakin hari semakin meningkat. Seperti halnya pada driver GO-JEK dan juga Grab Indonesia.

Adapun jumlah tingkat pengangguran di Indonesia saat ini adalah sebagai berikut: (BPS, 2018)

Tabel 1. Tingkat Pengangguran

\begin{tabular}{|c|c|c|c|}
\hline \multirow{2}{*}{ NO } & \multirow{2}{*}{ TAHUN } & \multicolumn{2}{|c|}{ TINGKAT PENGANGGURAN } \\
\cline { 3 - 4 } & & Februari & Agustus \\
\hline 1 & 2017 & 5,33 & 5,50 \\
\hline 2 & 2016 & 5,50 & 5,61 \\
\hline 3 & 2015 & 5,81 & 6,18 \\
\hline 4 & 2014 & 5,70 & 5,94 \\
\hline 5 & 2013 & 5,88 & 6,17 \\
\hline
\end{tabular}

Seiring perkembangan tingkat pembukaan cabang PT.GO-JEK pada 50 kota terakhir maka dengan hal itu tingkat pengangguran juga mengalami pertumbuhan yang cukup ber-fluktuatif.

Pada aspek mikro juga dapat di analisis bahwa pengangguran ini jugalah yang akan mempengaruhi tingkat kesejahteraan masyarakat. Indonesia.di karenakan pengangguran akan berimbas pada menurunnya tingkat perekenomian Negara, berdampak pada ketidak stabilan politik, berdampak pada para investor, dan pada sosial dan mental. Banyak sekali dampak yang ditimbulkan dari pengangguran. Beberapa dampak yang timbul oleh pengangguran :

1. Ditinjau dari segi Ekonomi Pengangguran akan meningkatkan jumlah kemiskinan. Karena banyaknya yang menganggur berdampak rendahnya pendapata ekonomi mereka. 
sementara biaya hidup terus berjalan.

2. Ditinjau dari segi sosial, dengan banyaknya pengangguran yang terjadi maka akan meningkatnya jumlah kemiskinan, dan banyaknya pengemis, gelandangan, serta pengamen. Hal ini dapat berpengaruh terhadap tingkat kriminal, karena sulitnya mencari pekerjaan, maka banyak orang melakukan tindak kejahatan seperti mencuri,merampok, dan lain-lain untuk memenuhi kehidupan mereka.

3. Ditinjau dari segi mental, dengan banyaknya penganguran maka rendahnya kepercayaan diri , keputusan asa, dan akan menimbulkan depresi.

4. Ditinjau dari segi politik maka akan banyaknya demonstrasi yang terjadi. Yang akan membuat dunia politik menjadi tidak stabil, banyaknya demosntrasi para serikat kerja karena banyaknya pengangguran yang terjadi.

5. Ditinjau dari segi keamanan, banyaknya pengangguran membuat para pengangur melakukan tindak kejahatan demi menghidupi perekonomiannya, seperti merampok, mencuri, menjual narkoba, tindakan penipuan. Banyaknya pengangguran juga dapat meningkatkan Pekerja Seks komersial dikalangan muda, karena demi menghidupi ekonominya (riska, 2018).

Tingkat kesejahteraan suatu bangsa dapat dilihat dari tingkat penggunaan tenaga kerja para warganya. Banyaknya penduduk sebenarnya adalah aset berharga untuk meningkatkan kemakmuran bangsa. Banyaknya penduduk dengan aneka ragam kebutuhan menunjukkan tingginya permintaan terhadap hasil produksi. Sementara naik turunnya hasil produksi sangat tergantung pada faktor tenaga kerja.

\section{KAJIAN TEORI}

\section{Transportasi Online}

Transportasi merupakan dari beberapa definisi transportasi menurut beberapa ahli sebagai berikut: (Pandesolang, 2018)

Menurut Doni, Pengertian Sistem Transportasi online adalah salah satu bentuk dari penyelenggaraan Lalu Lintas dan Angkutan Jalan yang berjalan dengan mengikuti serta memanfaatkan perkembangan ilmu pengetahuan (teknologi). 
Ferri Alfadri: Pengaruh Adanya Transportasi Online

Menurut Ellen Sistem Transportasi online adalah bentuk dari pengembangan potensi dan peran transportasi nasional yang sekaligus mendukung pembangunan ekonomi dan pengembangan wilayah.

Pada umumnya banyak masyarakat yang menganggap bahwa pekerjaan para driver transportasi online ini adalah pekerjaan bagi orang-orang yang sudah putus asa untuk mencari pekerjaan lain, hal itu di karenakan mudah nya syarat dan aturan yang di berlakukan oleh perusahaan tersebut.

Namun seiring berkembangnya waktu para driver GO-RIDE semakin bertambah jumlah nya di setiap daerah bahkan banyak dari masyarakat lebih memilih memfokuskan pekerjaan driver ini menjadi pekerjaan yang utama dikarenakan beberapa hal yaitu: (Okezon, 2018)
a. Penghasilan Lebih Besar
b. Jam Kerja Flexible
c. Hobi Berkendara
d. Part-Time
e. Suka Bertemu Orang Baru/ sosial baru
f. Pengalaman Tempat Baru

\section{Tinjauan Hukum}

Transaksi berbasis aplikasi online pada hakekatnya adalah sebuah perikatan. Sebagaimana definisi perikatan yang dikemukakan oleh Subekti, bahwa suatu perikatan adalah suatu perhubungan hukum antara dua orang atau dua pihak, berdasarkan mana pihak yang satu berhak menuntut sesuatu hal dari pihak yang lain, dan pihak yang lain berkewajiban untuk memenuhi tuntutan itu (subekti, 1984).

Melihat kegiatan transaksi yang dilakukan dengan aplikasi, maka terpenuhi definisi perikatan tersebut dimana terdapat lebih dari satu pihak, yang saling memiliki hak yang wajib dipenuhi oleh para pihak, dan harus menunaikan kewajiban pula kepada para pihak.

Beberapa pihak yang terlibat dalam transaksi berbasis aplikasi ini, yaitu : Perusahaan yang memiliki aplikasi perangkat lunak, Pengemudi ojek (penyedia layanan), Konsumen, restoran, toko, penyedia jasa lainnya. Perlu digaris bawahi penegasan bahwa perusahaan 
mereka adalah perusahaan teknologi, dengan demikian perusahaan seperti Go-Jek, Grab dan Uber tidak perlu untuk mengurus ijin usaha dibidang transportasi. Dengan kata lain, mereka hanyalah sebagai penghubung antara calon penumpang atau calon pengguna jasa dengan pengemudi sebagai penyedia layanan.

Pasal 1618 KUHPerdata mendefisikan persekutuan sebagai suatu persetujuan dengan mana dua orang atau lebih mengikatkan diri untuk memasukkan sesuatu dalam persekutuan, dengan maksud untuk membagi keuntungan yang terjadi karenanya. Selanjutnya Pasal 1619 menentukan bahwa masing-masing sekutu wajib memasukkan suatu modal sebagai inbreng, baik berupa barang, uang ataupun kerajinan atau tenaganya (Subekti, 1992).

\section{Ketenagakerjaan}

Menurut Undang-Undang Nomor 13 Tahun 2003 tentang ketenagakerjaan, Ketenagakerjaan adalah segala hal yang berhubungan dengan tenaga kerja pada waktu sebelum, selama, dan sesudah masa kerja (Kemenprint, 2017).

Badan Pusat Statistik pada tahun sekitar 1970-an menentukan batas usia kerja bila seseorang berumur 10 tahun atau lebih. Semenjak dilaksanakan SAKERNAS (Survei Angkatan Kerja) batas usia kerja dirubah menjadi 15 tahun atau lebih, ini dilaksanakan karena dianjurkan oleh International Labour Organization (ILO) (Handayani, 2016).

\section{Pengangguran}

Pengangguran merupakan suatu ukuran yang dilakukan jika seseorang tidak memiliki pekerjaan tetapi mereka sedang melakukan usaha secara aktif dalam empat minggu terakhir untuk mencari pekerjaan (Kaufman, 1999). Pengangguran merupakan suatu keadaan dimana seseorang yang tergolong dalam kategori angkatan kerja (Labor Force) tidak memiliki pekerjaan dan secara aktif tidak sedang mencari pekerjaan (Nanga, 2005). Pengangguran merupakan suatu keadaan di mana seseorang yang tergolong dalam angkatan kerja ingin mendapatkan pekerjaan tetapi mereka belum dapat memperoleh pekerjaan tersebut (Sadono Sukirno, 2006).

Pengangguran merupakan salah satu penyakit ekonomi yang sangat berpengaruh terhadap tingkat pertumbuhan ekonomi. Pengangguran mengakibatkan orang tidak memiliki pendapatan dan mendorong mereka jatuh menjadi miskin. Secara umum pemerintah 
Ferri Alfadri: Pengaruh Adanya Transportasi Online

mengatasi pengangguran dengan mengupayakan memperluas kesempatan kerja, baik di sektor pemerintahan maupun sektor swasta. Pengangguran dapat di pengaruhi oleh beberapa faktor sebagai berikut:

a. Jumlah Lapangan Pekerjaan

b. Modal

c. Tingkat Pendidikan

\section{Kesejahteraan Masyarakat}

Kementerian Koordinator Kesejahteraan Rakyat memberi pengertian sejahtera yaitu suatu kondisi masyarakat yang telah terpenuhi kebutuhandasarnya. Kebutuhan dasar tersebut berupa kecukupan dan mutu pangan,sandang, papan, kesehatan, pendidikan, lapangan pekerjaan, dan kebutuhan dasar lainnya seperti lingkungan yang bersih, aman dan nyaman. Juga terpenuhinya hak asasi dan partisipasi serta terwujudnya masyarakat berimandan bertakwa kepada Allah SWT (www.menkokesra.go.id, 2017).

Menurut Badan Pusat Statistik (BPS), Untuk memudahkan interpretasi, perubahan taraf kesejahteraan dikaji menurut delapan bidang yang mencakup Kependudukan, Pendapatan per-hari, Kesehatan dan Gizi, Pendidikan, Ketenagakerjaan, Taraf dan Pola Konsumsi, Perumahan dan Lingkungan, Kemiskinan, serta Sosial Lainnya yang menjadi acuan dalam upaya peningkatan kualitas hidup.pendapatan (www.bps.go.id, 2017).

\section{METODOLOGI}

Penelitian ini menggunakan data primer berupa angket dan wawancara sebagai observasi awal penelitian. Teknik analisis data yang digunakan adalah Component Based Structure Equation Model (SEM) dengan program Smart PLS.

TEMUAN DAN PEMBAHASAN HASIL PENELITIAN

Karakteristik Responden

Tabel 2 Jenis Kelamin

\begin{tabular}{|c|c|c|}
\hline No & Jenis Kelamin & Jumlah \\
\hline 1 & Laki - laki & 91 \\
\hline 2 & Perempuan & 9 \\
\hline & TOTAL & 100 \\
\hline
\end{tabular}

\begin{tabular}{|c|c|c|}
\hline No & Usia & Jumlah \\
\hline 1 & $18-25$ Tahun & 25 \\
\hline 2 & $26-36$ Tahun & 70 \\
\hline 3 & $>36$ Tahun & 5 \\
\hline \multicolumn{2}{|c|}{ TOTAL } & 100 \\
\hline
\end{tabular}


j-EBIS Vol. 3 No. 2 Juni 2018

Tabel 4 Tingkat Pendidikan

\begin{tabular}{|c|c|c|}
\hline No & Tingkat Pendidikan & Jumlah \\
\hline 1 & SMP/MTS/Sederajat & 1 \\
\hline 2 & SMA/SMK/MAN/sederajat & 72 \\
\hline 3 & D-III/S1/sederajat & 26 \\
\hline 4 & > S1 & 1 \\
\hline \multicolumn{2}{|c|}{ TOTAL } & 100 \\
\hline
\end{tabular}

Tabel 5 Pendapatan Per-Bulan

\begin{tabular}{|c|c|c|}
\hline No & Pendapatan & Jumlah \\
\hline 1 & Rp. $500.000-R p .1 .000 .000$ & 3 \\
\hline 2 & Rp. $1.000 .000,-R p .2 .000 .000$ & 13 \\
\hline 3 & Rp. $2.000 .000-R p .3 .000 .000$ & 59 \\
\hline 4 & Rp.3.000.000-Rp. 5.000 .000 & 25 \\
\hline TOTAL & 100 \\
\hline
\end{tabular}

\section{Struktural Equation Modeling dengan Smart PLS}

\section{a. Pengujian Kualitas Data}

Reliabilitas konstruk dalam penelitian ini akan diukur dengan menggunakan composite reliability. Suatu konstruk dapat dikatan reliabel jika nilai composite reliability diatas 0,60 (Ghozali, 2006).

Berdasarkan hasil pengujian menunjukkan bahwa semua konstruk atau variabel Transportasi Online (X), Tingkat Pengangguran ( $\mathrm{Y}$ ) dan kesejahteraan masyarakat $(\mathrm{Z})$ dinilai reliabel atau fit, hal ni berarti bahwa semua item pertanyaan yang digunakan untuk mengukur masing-masing konstruk sangat baik yaitu > 0,9. Hasil uji reliabilitas tersebut terlihat pada tabel dan lampiran penelitian.

Tabel 6 Hasil Uji composite reliability

\begin{tabular}{|l|c|}
\hline \multicolumn{1}{|c|}{ Konstruk } & Composite reliability \\
\hline Transportasi Online & 0,942 \\
\hline Tingkat Pengangguran & 0,919 \\
\hline Kesejahteraan Masyarakat & 0,932 \\
\hline
\end{tabular}

Ukuran refleksif individual dikatakan tinggi jika berkorelasi lebih dari 0.50 dengan konstruk yang ingin diukur. Konstruk dengan nilai loading faktor $>0.5$ bisa digunakan untuk mengukur model penelitian ini dan konstruk yang kurang dari 0.5 harus dihapus (Fatwa 
Ferri Alfadri: Pengaruh Adanya Transportasi Online

Tentama \& Subardjo, 2018). Pemenuhan validitas diskriminan dapat dilihat dari nilai cross loading konstruk. Jika korelasi indikator konstruk memiliki nilai lebih tinggi dibandingkan dengan korelasi indikator tersebut terhadap konstruk lain, maka dikatakan konstruk memiliki validitas diskriminan yang tinggi.

Tabel 7 Cross loading Indikator Antar Konstruk

\begin{tabular}{|c|c|c|c|c|}
\hline $\mathbf{N O}$ & Indikator & $\begin{array}{c}\text { Transportasi } \\
\text { Online }\end{array}$ & $\begin{array}{c}\text { Tingkat Pen- } \\
\text { gangguran }\end{array}$ & $\begin{array}{c}\text { Kesejahteraan } \\
\text { Masyarakat }\end{array}$ \\
\hline $\mathbf{1}$ & PL1 & 0,740 & 0,916 & 0,920 \\
\hline $\mathbf{2}$ & PL2 & 0,842 & 0,811 & 0,795 \\
\hline $\mathbf{3}$ & FX1 & 0,908 & 0,889 & 0,857 \\
\hline $\mathbf{4}$ & FX2 & 0,710 & 0,617 & 0,616 \\
\hline $\mathbf{5}$ & HB1 & 0,871 & 0,812 & 0,861 \\
\hline $\mathbf{6}$ & HB2 & 0,704 & 0,653 & 0,646 \\
\hline $\mathbf{7}$ & PT1 & 0,713 & 0,629 & 0,673 \\
\hline $\mathbf{8}$ & PT2 & 0,857 & 0,832 & 0,857 \\
\hline $\mathbf{9}$ & SB1 & 0,627 & 0,581 & 0,652 \\
\hline $\mathbf{1 0}$ & SB2 & 0,557 & 0,561 & 0,469 \\
\hline $\mathbf{1 1}$ & PB1 & 0,531 & 0,472 & 0,415 \\
\hline $\mathbf{1 2}$ & PB2 & 0,954 & 0,916 & 0,920 \\
\hline $\mathbf{1 3}$ & LP1 & 0,746 & 0,810 & 0,743 \\
\hline $\mathbf{1 4}$ & LP2 & 0,699 & 0,722 & 0,717 \\
\hline $\mathbf{1 5}$ & MO1 & 0,932 & 0,954 & 0,925 \\
\hline $\mathbf{1 6}$ & MO2 & 0,657 & 0,767 & 0,685 \\
\hline $\mathbf{1 7}$ & TP1 & 0,596 & 0,601 & 0,574 \\
\hline $\mathbf{1 8}$ & TP2 & 0,921 & 0,958 & 0,929 \\
\hline $\mathbf{1 9}$ & PDT1 & 0,522 & 0,505 & 0,619 \\
\hline $\mathbf{2 0}$ & PDT2 & 0,637 & 0,624 & 0,715 \\
\hline $\mathbf{2 1}$ & KO1 & 0,820 & 0,752 & 0,808 \\
\hline $\mathbf{2 2}$ & KO2 & 0,577 & 0,626 & 0,715 \\
\hline $\mathbf{2 3}$ & KES1 & 0,722 & 0,722 & 0,761 \\
\hline $\mathbf{2 4}$ & KES2 & 0,719 & 0,688 & 0,756 \\
\hline $\mathbf{2 5}$ & LK1 & 0,851 & 0,882 & 0,853 \\
\hline $\mathbf{2 6}$ & LK2 & 0,668 & 0,714 & 0,779 \\
\hline $\mathbf{2 7}$ & KS1 & 0,836 & 0,818 & 0,835 \\
\hline $\mathbf{2 8}$ & KS2 & 0,725 & 0,750 & 0,757 \\
\hline & & & & \\
\hline
\end{tabular}

Berdasarakan standar nilai yang direkomendasikan dalam hal menilai tingkat validitas maka, data dalam penelitian ini diategorikan valid dikarenakan > 0,5 (Ghozali, 2006).

struktural dievaluasi dengan menggunakan R-square untuk variabel dependen dan uji t 156 
j-EBIS Vol. 3 No. 2 Juni 2018

serta signifikansi dari koefisien parameter jalur struktural. Tabel dan juga pada lampiran berikut ini merupakan hasil estimasi R-square dengan menggunakan Smart PLS.

Tabel 8 R Square

\begin{tabular}{|c|c|}
\hline Variabel & R Square \\
\hline Tingkat Pengangguran & 0,896 \\
\hline Kesejahteraan Masyarakat & 0,909 \\
\hline
\end{tabular}

\section{b. Model Penelitian}

Hasil perhitungan dengan menggunakan software PLS 3 diagram path dari model penelitian seperti di bawah ini.

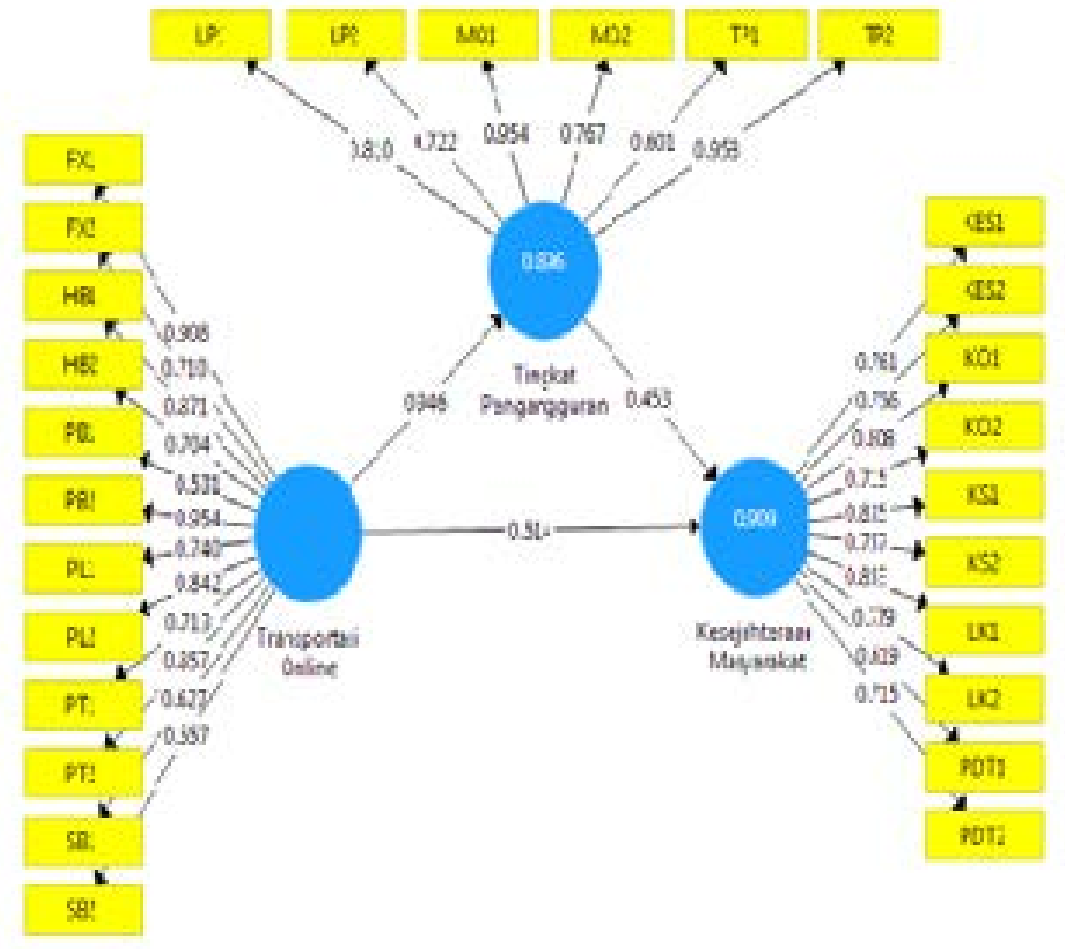

Gambar 2 Model Struktural Equation Model Penelitian

Model dari analisis data diatas akan di lihat loading factor dari setiap indikator. Dan hasilnya dapat dilihat pada tabel.

Tabel 9 Outer Loading Model

\begin{tabular}{|c|c|c|c|c|}
\hline NO & Indikator & $\begin{array}{c}\text { Transportasi } \\
\text { Online }\end{array}$ & $\begin{array}{c}\text { Tingkat Pen- } \\
\text { gangguran }\end{array}$ & $\begin{array}{c}\text { Kesejahteraan } \\
\text { Masyarakat }\end{array}$ \\
\hline $\mathbf{1}$ & PL1 & 0,740 & & \\
\hline
\end{tabular}


Ferri Alfadri: Pengaruh Adanya Transportasi Online

\begin{tabular}{|c|c|c|c|c|}
\hline 2 & PL2 & 0,842 & & \\
\hline 3 & $\mathrm{FX} 1$ & 0,908 & & \\
\hline 4 & $\mathrm{FX} 2$ & 0,710 & & \\
\hline 5 & HB1 & 0,871 & & \\
\hline 6 & $\mathrm{HB} 2$ & 0,704 & & \\
\hline 7 & PT1 & 0,713 & & \\
\hline 8 & PT2 & 0,857 & & \\
\hline 9 & SB1 & 0,627 & & \\
\hline 10 & $\mathrm{SB} 2$ & 0,557 & & \\
\hline 11 & PB1 & 0,531 & & \\
\hline 12 & PB2 & 0,954 & & \\
\hline 13 & LP1 & & 0,810 & \\
\hline 14 & LP2 & & 0,722 & \\
\hline 15 & MO1 & & 0,954 & \\
\hline 16 & $\mathrm{MO} 2$ & & 0,767 & \\
\hline 17 & TP1 & & 0,601 & \\
\hline 18 & TP2 & & 0,958 & \\
\hline 19 & PDT1 & & & 0,619 \\
\hline 20 & PDT2 & & & 0,715 \\
\hline 21 & KO1 & & & 0,808 \\
\hline 22 & $\mathrm{KO} 2$ & & & 0,715 \\
\hline 23 & KES1 & & & 0,761 \\
\hline 24 & KES2 & & & 0,756 \\
\hline 25 & LK1 & & & 0,853 \\
\hline 26 & LK2 & & & 0,779 \\
\hline 27 & KS1 & & & 0,835 \\
\hline 28 & KS2 & & & 0,757 \\
\hline
\end{tabular}

Nilai minimal loading yang digunakan adalah lebih besar dari $\pm 0,30$; loading $\pm 0,40$ dianggap penting ; dan loading $\pm 0,50$ atau lebih besar dinyatakan signifikan.

Dari tabel di atas dapat diketahui bahwa model indikator yang telah di olah dapat dinyatakan fit di karenakan semua loading factornya > 0,50. Maka model tersebut dapat dilanjutkan dengan melihat hasil validitas indikator dan reliabilitas konstruk (Ghozali, 2006).

\section{c. Pengujian Validitas Konstruk}

Dilakukan untuk mengetahui nilai T statistik dari seluruh indikator pembentuk konstruk. Indikator yang memiliki nilai T statistik lebih besar atau sama dengan 1,96 dikatakan valid. Indikator juga dikatakan valid jika $\mathrm{P}$ value lebih besar atau sama dengan 0,05. Dari 
j-EBIS Vol. 3 No. 2 Juni 2018

perhitungan PLS Bootstraping dari model di atas di peroleh tabel Outer Loading seperti dibawah (Ghozali, 2006).

Tabel 10 Outer Loading Pembentuk Konstruk

\begin{tabular}{|c|c|c|c|c|c|}
\hline Indikator & $\begin{array}{l}\text { Original } \\
\text { Sample } \\
\text { (O) }\end{array}$ & $\begin{array}{c}\text { Sample } \\
\text { Mean } \\
\text { (M) }\end{array}$ & $\begin{array}{l}\text { Standard } \\
\text { Deviation } \\
\text { (STDEV) }\end{array}$ & $\begin{array}{l}\text { T Statistics } \\
\text { (JO/STDEV/) }\end{array}$ & $\begin{array}{c}\mathbf{P} \\
\text { Values }\end{array}$ \\
\hline PL1 <-Transportasi Online & 0,740 & 0,739 & 0,058 & 12,455 & 0,000 \\
\hline PL2<-Transportasi Online & 0,842 & 0,841 & 0,030 & 28,155 & 0,000 \\
\hline FX1<-Transportasi Online & 0,908 & 0,907 & 0,026 & 35,114 & 0,000 \\
\hline FX2<-Transportasi Online & 0,710 & 0,711 & 0,077 & 9,196 & 0,000 \\
\hline HB1<-Transportasi Online & 0,871 & 0,870 & 0,036 & 24,452 & 0,000 \\
\hline HB2<-Transportasi Online & 0,704 & $0,, 697$ & 0,056 & 12,571 & 0,000 \\
\hline PT1<-Transportasi Online & 0,713 & 0,707 & 0,065 & 10,954 & 0,000 \\
\hline PT2<-Transportasi Online & 0,857 & 0,858 & 0,029 & 30,011 & 0,000 \\
\hline SB1<-Transportasi Online & 0,627 & 0,623 & 0,085 & 7,420 & 0,000 \\
\hline SB2<-Transportasi Online & 0,557 & 0,560 & 0,065 & 8,509 & 0,000 \\
\hline PB1<-Transportasi Online & 0,531 & 0,529 & 0,081 & 6,526 & 0,000 \\
\hline PB2<-Transportasi Online & 0,954 & 0,954 & 0,007 & 132,101 & 0,000 \\
\hline LP1<-Tingkat Pengangguran & 0,810 & 0,805 & 0,046 & 17,740 & 0,000 \\
\hline LP2<-Tingkat Pengangguran & 0,722 & 0,720 & 0,055 & 13,182 & 0,000 \\
\hline MO1<-Tingkat Pengangguran & 0,954 & 0,954 & 0,008 & 119.983 & 0.000 \\
\hline MO2<-Tingkat Pengangguran & 0,767 & 0,764 & 0,055 & 13.959 & 0.000 \\
\hline TP1<-Tingkat Pengangguran & 0,601 & 0,604 & 0,080 & 7,560 & $0, \infty 00$ \\
\hline TP2 $<-$ Tingkat Pengangguran & 0,958 & 0,959 & 0,006 & 149,416 & 0,000 \\
\hline PDTicKesejahteraan & 0,619 & 0,615 & 0,085 & 7,326 & $0, \infty 00$ \\
\hline PDTzckesejahteraan & 0,715 & 0,711 & 0,057 & 12,455 & $0, \infty 00$ \\
\hline
\end{tabular}


Ferri Alfadri: Pengaruh Adanya Transportasi Online

\begin{tabular}{l|c|c|c|c|c|}
\hline KO1<Kesejahteraan & 0,808 & 0,807 & 0,045 & 17,896 & 0,000 \\
\hline KO2<Kesejahteraan & 0,715 & 0,708 & 0,081 & 8,853 & 0,000 \\
\hline KES1<Kesejahteraan & 0,761 & 0,763 & 0,067 & 11,327 & 0,000 \\
\hline KES2<Kesejahteraan & 0,756 & 0,755 & 0,059 & 12,818 & 0,000 \\
\hline LK1<Kesejahteraan & 0,853 & 0,856 & 0,035 & 24,449 & 0,000 \\
\hline LK2<Kesejahteraan & 0,779 & 0,780 & 0,076 & 10,259 & 0,000 \\
\hline KS1<Kesejahteraan & 0,835 & 0,835 & 0,035 & 23,816 & 0,000 \\
\hline KS2<Kesejahteraan & 0,757 & 0,757 & 0,057 & 13,241 & 0,000 \\
\hline
\end{tabular}

Dari tabel di atas dapat dilihat bahwa semua indikator pembentuk konstruk memiliki T statistik di atas 1,96 dan P Value di bawah 0,05 sehingga dapat dinyatakan bahwa semua indikator pembentuk konstruk valid dan dapat digunakan untuk menguji hipotesis pada tahap pengukuran struktural.

\section{d. Evaluasi Model Struktural}

Evaluasi model analisis digunakan untuk melihat signifikansi hubungan antar konstruk yang ditunjukkan dengan nilai $T$ statistik yang dihasilkan dari output dengan menggunakan perintah calculate PLS Bootstraping. Besarnya pengaruh antar konstruk dan efek interaksi (moderasi) diukur dengan nilai koefisien jalur (path coefficient). path coefficient yang memiliki nilai $T$ statistik $\geq 1,96$ atau memiliki $P$ Value $\leq 0,05$ di nyatakan signifikan (Ghozali, 2006).Dengan menggunakan software Smart PLS 3 maka di peroleh path diagram dan nilai T statistik dan tabel dari path coefficient seperti di bawah:

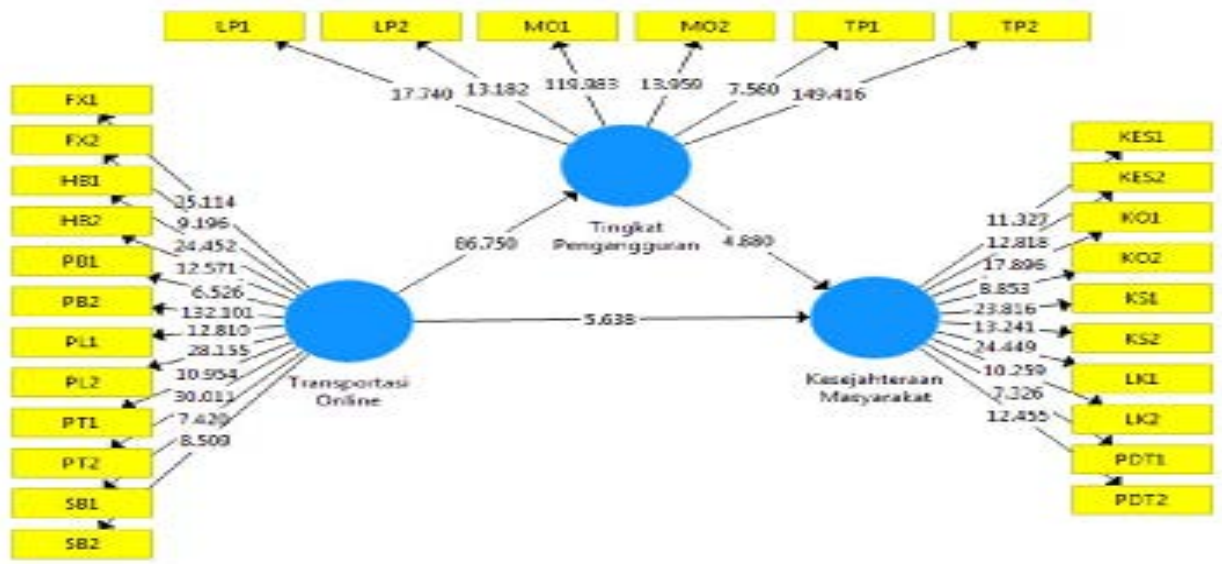


j-EBIS Vol. 3 No. 2 Juni 2018

\section{Gambar 4.3 Path Diagram dan T statistik}

Tabel 4. 25 Uji T dan Signifikan P Value

\begin{tabular}{|c|c|c|c|c|c|}
\hline & $\begin{array}{c}\text { Original } \\
\text { Sample } \\
\text { (O) }\end{array}$ & $\begin{array}{c}\text { Sample } \\
\text { Mean (M) }\end{array}$ & $\begin{array}{l}\text { Standard } \\
\text { Deviation } \\
\text { (STDEV) }\end{array}$ & $\begin{array}{l}\text { T Statistics } \\
(/ \mathrm{O} / \mathrm{STDEV} /)\end{array}$ & $\underset{\text { Values }}{\mathbf{P}}$ \\
\hline $\begin{array}{c}\text { Transportasi Online -> } \\
\text { Kesejahteraan }\end{array}$ & 0,514 & 0,528 & 0,091 & 5,638 & 0,000 \\
\hline $\begin{array}{l}\text { Transportasi Online -> } \\
\text { Tingkat Pengangguran }\end{array}$ & 0,946 & 0,948 & 0,011 & 86,750 & 0,000 \\
\hline ingkat Pengangguran-> & 0,453 & 0,440 & 0,093 & 4,880 & 0,000 \\
\hline Kesejahteraan & & & & & \\
\hline
\end{tabular}

Berdasarkan tabel di atas dapat dilakukan pengujian hipotesis. Dilakukan terhadap 3 hipotesis yang di ajukan. Pengujian hipotesis dilakukan dengan membandingkan nilai T-Value dengan signifikansi 0,05. Jika T-Value $\geq 1,96$ atau P-Value $\leq$ 0,05 maka Ho ditolakatau hipotesis penelitian diterima.

Ho : menyatakan bahwa variabel eksogen tidak mempengaruhi variabel endogen $\mathrm{H} 1$ : menyatakan bahwa variabel eksogen mempengaruhi variabel endogen

Pengambilan keputusan dengan membandingkan $\mathrm{T}$ statistic hitung dan T tabel atau P Value sehingga jika :

?] Jika statistik T hitung < dari T tabel dan $\mathrm{P}>0,05$ maka Ho ditolak

? Jika statistik T hitung $>$ dari T tabel dan $\mathrm{P}<0,05$ maka Ho diterima

\section{PEMBAHASAN HIPOTESIS}

\section{Adanya Sistem Transportasi Online (GO-JEK) dalam mengurangi tingkat Pengangguran.}

Berdasarkan hasil perhitungan statistik pada penelitian ini, maka dapat dsimpulkan bahwa konstruk adanya transportasi online berpengaruh positif sifnifikan terhadap konstruk pengurangan tingkat pengangguran secara langsung. Hal ini dapat di buktikan dari nilai t-statistik yang jauh lebih besar dari 1,96 yakni sebesar 86,750. Dengan demikian, hipotesis $\mathrm{H} 1$ dalam penelitian ini diterima. 
Ferri Alfadri: Pengaruh Adanya Transportasi Online

Hal ini juga menunjukkan bahwa dengan hadirnya lapangan pekerjaan dengan menggunakan Sistem transportasi online ini telah mampu menjadi salah satu alternatif solusi dalam menekan angka pengangguran di karenakan telah membuka lapangan pekerjaan baru di kota Medan yang berdampak cukup baik untuk mengurangi tingkat pengangguran di kota Medan bahkan banyak dari para driver mengaku bahwa dengan adanya sistem transportasi online ini dan membantu menambah pendapatan mereka walaupun ada dasarnya sudah bekerja atau punya pekerjaan tetap.

\section{Pengaruh adanya transportasi online (GO-JEK) dalam mensejahterakan}

Berdasarkan hasil perhitungan statistik pada penelitian ini, maka dapat dsimpulkan bahwa konstruk adanya transportasi online berpengaruh positif sifnifikan terhadap konstruk Kesejahteraan secara langsung. Hal ini dapat di buktikan dari nilai t-statistik yang lebih besar dari 1,96 yakni sebesar 5,638.

Dengan demikian, hipotesis $\mathrm{H} 1$ dalam penelitian ini diterima. Hal ini juga menunjukkan bahwa dengan hadirnya lapangan pekerjaan dengan menggunakan Sistem transportasi online ini telah mampu mensejahterakan kehidupan para driver GO-JEK beserta keluarganya baik secara fisik (yang tampak) ataupun yang bersifat batiniah seperti adanya kebebasan waktu beribadah kepada Allah Subhana' Wata'ala.

\section{Pengaruh adanya transportasi online dalam mensejahterakan melalui pengurangan tingkat pengangguran}

Berdasarkan hasil perhitungan statistik pada penelitian ini, maka dapat dsimpulkan bahwa konstruk adanya transportasi online berpengaruh positif sifnifikan terhadap konstruk Kesejahteraan secara langsung. Hal ini dapat di buktikan dari nilai t-statistik yang lebih besar dari 1,96 yakni sebesar 4,880.

Dengan demikian, hipotesis $\mathrm{H} 1$ dalam penelitian ini diterima. Hal ini juga menunjukkan bahwa dengan hadirnya lapangan pekerjaan dengan menggunakan Sistem transportasi online ini telah mampu mensejahterakan kehidupan masyarakat (para driver GOJEK beserta keluarganya) melalui pengurangan tingkat pengangguran.

\section{DAFTAR PUSTAKA}

Erutan, Agas Punu Anto', Jurnal Ilmu Sosial dan Ilmu Politik, ISSN 1,410-4946, Volume 10, Nomor 3, Maret2\}A7 Q95-324) 
j-EBIS Vol. 3 No. 2 Juni 2018

Franita, Riska, Analisa Pengangguran di Indonesia, Nusantara( Jurnal Ilmu Pengetahuan Sosial ), Volume 1 Desember 2016, ISSN 2541-657X

Ghozali, Imam, Struktural Equation Modeling Metode Alternatif dengan Partial Least Square, (Badan Penerbit Universitas Diponegoro, 2006),

Handayani, eprints.walisongo.ac.id

http://belajarpsikologi.PengertianTransportasi/Online.com

http://rubik.okezone.com/read/40747/10-alasan-menjadi-driver-transportasi-onlineJurnal Kewirausahaan dan Bisnis, Vol 21, No 11 (2017)

Kaufman, Bruce E Julie L.Hotchkiss, The Economics Of Labor Market,Yogyakarta 1999, BPFE UGM

Martati, Indah, Jurnal Manajemen Dan Kewirausahaan/Jmk, Vol.15, No. 2, September 2013: $123-130$

Muana, Nanga, Makro Ekonomi Teori Masalah dan Kebijakan, (Jakarta,PT.Raja Grafindo Persada,2005)

Pandesolang, e-journal.uajy.ac.id/7732/3/TA213706.pdf

R.Tjitrosudibio Subekti,, Kitab Undang Undang Hukum Perdata, (Pradnya Pramita, Jakarta, 1992)

Subekti, Hukum Perjanjian, (PT.Intermasa, Jakarta, 1984)

Sukirno, Sadono, Makro Ekonomi Teori Pengantar, (Jakarta: PT. Raja Grafindo Persada, 2006)

Tentama, Fatwa \& Subardjo, Jurnal HUMANITAS, Pengujian Validitas dan Reliabilitas Konstruk Pada Organizational Citizenship Behavior, ISSN 1693-7236, Vol. 15 , No.1

wWw.BPS.go.id

www.bps.go.id/publication/2017/11/28

www.kemenperin.Go.id/Kompetensi/UU_13_2003

www.menkokesra.go.id., 